\title{
GAMBARAN HISTOLOGIK HEPAR HEWAN COBA POSTMORTEM
}

\author{
Novia K. Pualillin \\ Sunny Wangko \\ Sonny J. R. Kalangi
}

\author{
Bagian Anatomi-Histologi Fakultas Kedokteran Universitas Sam Ratulangi \\ Manado \\ Email: opypualillin@gmail.com
}

\begin{abstract}
The usage of postmortem histological changes of the liver in the medicolegal investigation is still very limited. This study aimed to obtain the histological changes of the liver postmortem. This was an experimental-descriptive study using one pig as model. Samples were taken from its liver after 0 minute; 15 minutes; 30 minutes; 45 minutes; 60 minutes; 12 hours; and 24 hours postmortem. The results showed that the first postmortem histological changes of the pig liver were observed 30 minutes postmortem. These changes were congestion of the liver parenchym and sinusoidal dilatation, which became more distinct after 45 and 60 minutes. At 12 hours postmortem, the hexagonal forms of lobuli could still be identified, however, most central veins and vessels in the portal areas could not be identified. At 24 hours postmortem, liver lobuli and all the vessels could not be identified. Conclusion: The earliest histological changes, parenchym congestion and sinusoiodal dilatation, occured 30 minutes postmortem. At 12 hours postmortem, most ot the vessels could not be identified. Morover, at 24 hours postmortem, all liver structures could not be identified anymore. It is expected that these postmortem histological changes of the liver colud be applied in medicolegal investigation especially $\leq 24$ hours postmortem.
\end{abstract}

Keywords: postmortem interval, liver, postmortem.

\begin{abstract}
Abstrak: Perubahan gambaran histologik hepar postmortem yang dijadikan dasar dalam penentuan lama kematian masih sangat terbatas. Penelitian ini bertujuan untuk mendapatkan gambaran histologik hepar postmortem. Penelitian ini bersifat deskriptif eksperimental dengan menggunakan babi sebagai hewan coba. Sampel jaringan hepar diambil pada interval waktu 0 menit; 15 menit; 30 menit; 45 menit; 60 menit; 12 jam; dan 24 jam postmortem. Hasil penelitian memperlihatkan perubahan histologik hepar babi mulai teridentifikasi pada 30 menit postmortem berupa kongesti parenkim hepar disertai dilatasi sinusoid. Pada 45 menit dan 60 menit postmortem, perubahan-perubahan di atas makin nyata dan meluas. Pada 12 jam postmortem, bentuk lobuli heksagonal masih dapat diidentifikasi tetapi sebagian besar vena sentralis dan pembuluh-pembuluh dalam area portal tidak dapat diidentifikasi lagi. Pada 24 jam postmortem, lobuli hepar, vena sentralis serta pembuluh-pembuluh dalam area portal tidak dapat diidentifikasi lagi. Simpulan: Perubahan gambaran histologik hepar babi mulai tampak pada 30 menit postmortem ditandai kongesti parenkim hepar disertai dilatasi sinusoid. Pada 12 jam postmortem, sebagian besar pembuluh-pembuluh tidak dapat diidentifikasi lagi. Pada 24 jam postmortem seluruh struktur hepar tidak dapat diidentifikasi lagi. Penelitian ini diharapkan dapat diaplikasikan untuk kepentingan medikolegal, terutama pada kematian $\leq 24$ jam.
\end{abstract}

Kata kunci: lama kematian, hepar, postmortem. 
Mati adalah berhentinya semua fungsi vital tubuh yang permanen. Untuk kegunaan hukum dan kedokteran, diusulkan definisi mati sebagai berhentinya semua fungsi otak, fungsi sistem respirasi, dan fungsi sistem sirkulasi secara spontan tanpa bisa pulih kembali. ${ }^{1}$

Perubahan-perubahan fisik pada mayat yang dapat diamati secara kasat mata mempunyai pola tertentu yang memungkinkan untuk dimanfaatkan dalam perkiraan saat kematian atau postmortem interval (PMI), yaitu antara lain: penurunan suhu tubuh, lebam mayat, kaku mayat, pembusukan (dekomposisi), adipocere, mumifikasi, serta terjadinya perubahanperubahan biokimiawi. ${ }^{2}$ Selain itu, terjadi pelunakan atau pencairan jaringan dalam keadaan steril yang disebut autodigesti atau autolisis akibat kerja enzim-enzim digestif yang dilepaskan oleh sel-sel. ${ }^{2,3}$ Perkembangan perubahan-perubahan tersebut sangat dipengaruhi oleh suhu, kelembaban, dan keadaan sekitar. ${ }^{4,5}$

Dewasa ini ilmu pengetahuan dan teknologi di bidang kedokteran semakin berkembang pesat, di antaranya dalam bidang biokimia, histologi, histokimiawi, dan forensik. ${ }^{4}$ Walaupun demikian, perkiraan saat kematian atau postmortem interval (PMI) yang akurat masih tetap merupakan masalah pelik dalam bidang forensik. Penelitian-penelitian postmortem telah mengemukakan berbagai perubahan di tingkat intra dan ekstrasel baik pada satu organ maupun berbagai organ, namun keberadaan perubahan-perubahan tersebut belum dapat ditetapkan sebagai salah satu kriteria dalam praktek forensik untuk perkiraan saat kematian.,

Penelitian mengenai gambaran histologik postmortem dari organ-organ termasuk hepar sebagai alternatif perkiraan waktu kematian belum banyak dilakukan dan masih kurang yang membahasnya. Umumnya penelitian-penelitian tersebut menggunakan hewan coba tikus. ${ }^{3-9}$ Penelitian ini menggunakan babi sebagai hewan coba karena babi tergolong hewan omnivora dengan pola dekomposisi, struktur histologik organ-organ termasuk hepar, flora saluran cerna, dan histofisiologi kulit menyerupai manusia. ${ }^{11-14}$

\section{METODE PENELITIAN}

Penelitian ini merupakan penelitian deskriptif-eksperimental yang dilakukan di Bagian Anatomi-Histologi dan Animal House Fakultas Kedokteran Universitas Sam Ratulangi Manado, serta Pusat Diagnostik Patologi Anatomi Manado mulai 30 November 2013 sampai dengan Januari 2014. Hewan coba yang digunakan ialah satu ekor babi dengan berat $20 \mathrm{~kg}$ yang secara fisik aktif, sehat, dan tanpa luka.

\section{Prosedur penelitian}

Hewan coba dimatikan dengan ditusuk tepat pada jantung. Setelah hewan coba berhenti bernapas, dicatat waktu kema-tian. Dilakukan pengambilan sampel hepar pada interval waktu 0 menit, 15 menit, 30 menit, 45 menit, 60 menit, 12 jam dan 24 jam dengan prosedur sebagai berikut: Dilakukan irisan pada daerah tulang rusuk kanan yang paling bawah. Irisan diperdalam secara tumpul menggunakan klem sampai teraba hepar. Potongan jaringan hepar diambil sebesar 1x1x1 cm ${ }^{3}$, lalu kulit abdomen dirapatkan kembali setelah setiap kali pengambilan sampel. Semua sampel difiksasi dengan formalin $10 \%$ dan disiapkan untuk pembuatan sediaan histologik dengan pewarnaan hematoksillin eosin. Sediaan histologik diidentifikasi dengan mikroskop cahaya Olympus CX 21 dan Optilab viewer.

\section{HASIL PENELITIAN}

\section{Lobuli dan vena sentralis}

Gambaran histologik lobuli dan vena sentralis postmortem dengan pembesaran $4 \mathrm{x}$ diidentifikasi dengan berbagai variasi interval waktu.

Pada 0 menit postmortem, tampak lobuli dipisahkan satu dari lainnya oleh jaringan ikat yang jelas. Bentuk lobuli heksagonal dengan vena sentralis berada ditengah. Pada 15 menit postmortem belum 
tampak perubahan histologik baik dari lobuli, parenkim hepar, maupun vena sentralis (Gambar 1).

Pada 30 menit postmortem, mulai tampak kongesti jaringan parensim hepar disertai dilatasi sinusoid. Bentuk lobuli dan vena sentralis masih dapat diidentifikasi, serta tampak celah interlobuli (Gambar 2).

Pada 45 menit dan 60 menit postmortem, kongesti jaringan parenkim hepar bertambah, disertai dilatasi sinusoid dan vena sentralis. Celah antara jaringan parenkim lobuli dan jaringan ikat interlobuli makin nyata (Gambar 3). Sebagian kecil jaringan ikat yang membatasi lobuli tampak terputus-putus bila diamati dengan pembesaran 40x. Bentuk lobuli yang heksagonal dan vena sentralis masih dapat diidentifikasi.

Pada 12 jam postmortem, perubahan histologik tersebut di atas makin meluas, bentuk lobuli heksagonal masih dapat diidentifikasi tetapi vena sentralis tidak tampak jelas (Gambar 4).

Pada 24 jam postmortem, lobuli hepar dan vena sentralis tidak dapat diidentifikasi lagi (Gambar 5).

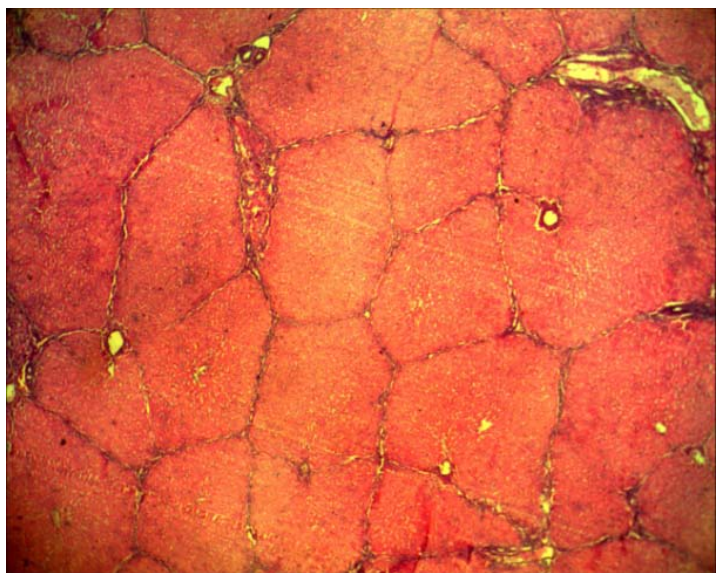

Gambar 1. Lobuli hepar 15 menit postmortem (4x).

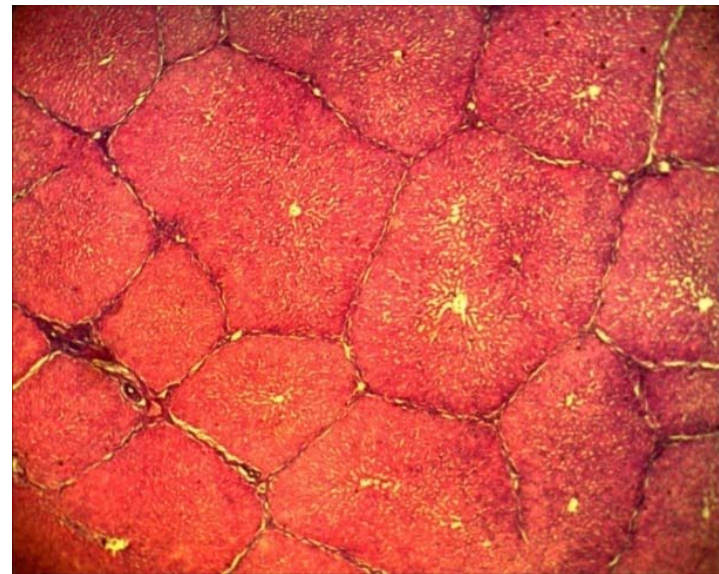

Gambar 2. Lobuli hepar 30 menit postmortem (4x).

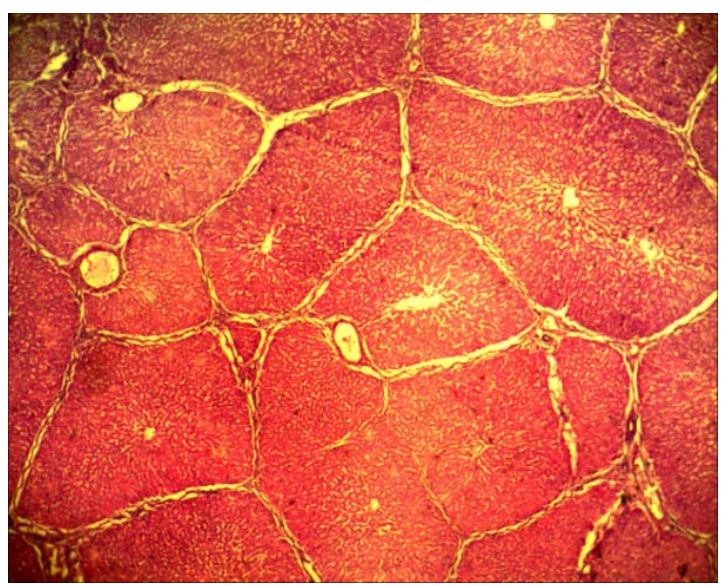

Gambar 3. Lobuli hepar 60 menit postmortem (4x).

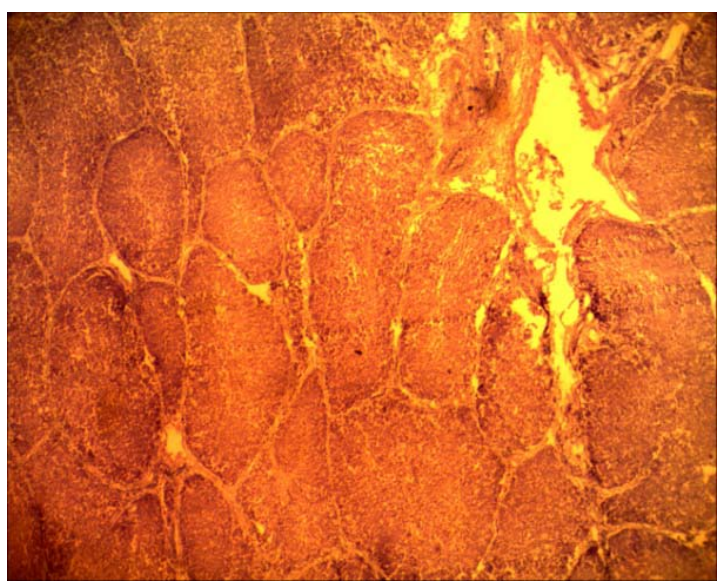

Gambar 4. Lobuli hepar 12 jam postmortem (4x). 


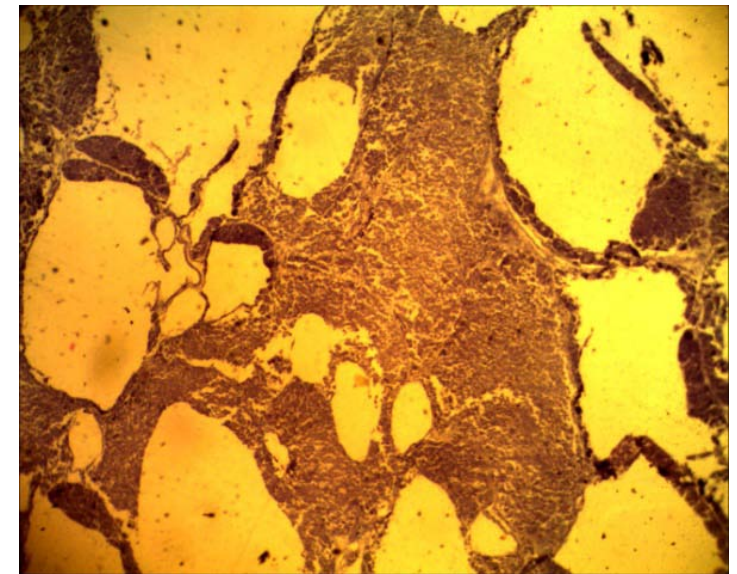

Gambar 5. Lobuli hepar 24 jam postmortem $(4 x)$.

\section{Area portal dan pembuluh-pembuluhnya}

Pada 0 menit postmortem, pembuluhpembuluh yang dapat diidentifikasi dalam area portal ialah cabang-cabang arteri hepatika, vena porta, dan duktus biliaris (Gambar 6).

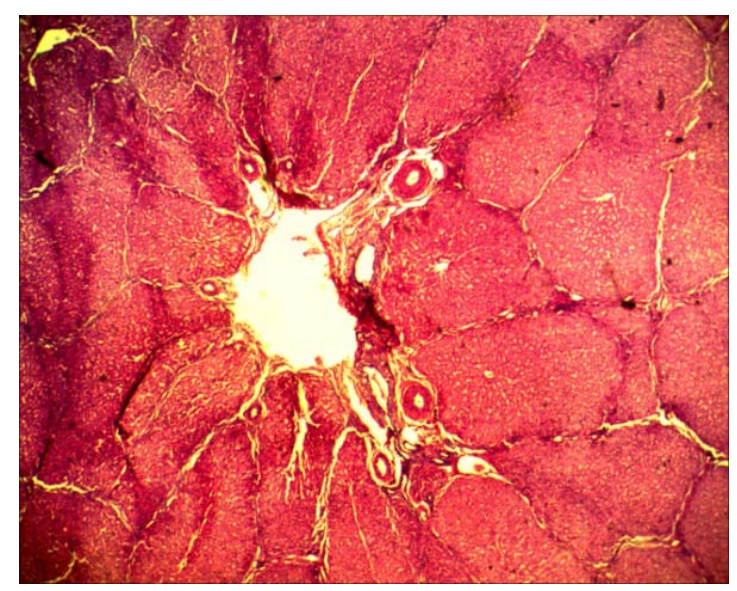

Gambar 6. Area portal 0 menit postmortem (10x).

Sampai dengan 60 menit postmortem pembuluh-pembuluh dalam area portal masih dapat diidentifikasi (Gambar 7). Pada 12 jam postmortem, sebagian besar pembuluh-pembuluh tersebut tidak dapat diidentifikasi lagi dengan jelas (Gambar 4). Pada 24 jam postmortem, area portal dan pembuluh-pembuluh di dalamnya tidak dapat diidentifikasi lagi (Gambar 5).

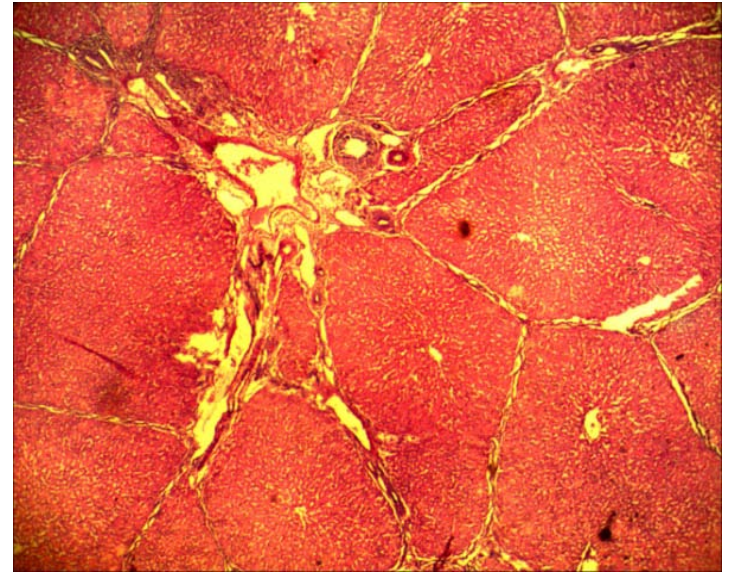

Gambar 7. Area portal 60 menit postmortem (10x).

\section{BAHASAN}

Umumnya penelitian postmortem yang dilakukan baik pada hepar hewan coba maupun mayat manusia ditujukan pada ultrastruktur parenkim hepar. $3,5,7,8,15$ Beberapa penelitian mengenai perubahan ultrastruktur dengan menggunakan hewan coba tikus memperlihatkan hasil yang bervariasi. Tomita et al. (1999) $)^{7}$ meneliti ultrastruktur beberapa organ termasuk hepar dan mendapatkan perubahan yang paling dini pada hepar diidentifikasi pada 5 jam postmortem berupa vakuolisasi sitoplasma hepatosit. Kimura et al. ${ }^{15}$ mengemukakan adanya atrofi hepatosit, dilatasi sinusoid dan kariopiknosis sel endotel atau sel Kupffer pada $37,5^{\circ} \mathrm{C}$ yang meningkat setelah 5 jam postmortem. Karadzic et al. ${ }^{3}$ mendapatkan bahwa pada 2 jam postmortem dengan suhu $28^{0} \mathrm{C}$ membran inti hepatosit terlepas dalam bentuk tonjolan atau vakuola, serta edema membran retikulum endoplasma dan apparatus Golgi. Tomita et al. $(2004)^{5}$ melaporkan pada 1 jam postmortem telah terjadi edema hepatosit, penggumpalam kromatin inti, dan hilangnya krista mitokondria. $\mathrm{Li}$ et al. $^{8}$ mengemukakan terjadinya vakuolisasi hepatoselular fokal atau multifokal segera setelah tikus dieutanasia, yang makin bertambah dengan bertambahnya waktu. Hasil penelitianpenelitian di atas yang cukup bervariasi mungkin dipengaruhi oleh metode 
penelitian yang digunakan. Dengan melihat hasil-hasil tersebut dan kondisi setempat maka penelitian ini ditujukan ke perubahan-perubahan histologik yang dapat diamati dengan mikroskop cahaya.

Hasil penelitian Karadzic et al. ${ }^{3}$ yang menggunakan hepatosit tikus dan manusia memperlihatkan bahwa perubahan ultra struktur akibat autolisis pada manusia terjadi lebih lambat dibandingkan hepar tikus, yaitu perbedaan waktu sekitar 6-12 jam. Penelitian ini menggunakan babi sebagai hewan coba dan diharapkan bahwa perubahan histologik postmortem yang ditemukan lebih mendekati yang terjadi pada manusia dibandingkan bila menggunakan hewan coba tikus.

Secara histologik pada 0 menit postmortem (Gambar 1) bentuk lobuli heksagonal jelas terlihat dengan vena sentralis di tengah dan area portal dengan pembuluh-pembuluhnya. Pada 30 menit postmortem, mulai tampak kongesti jaringan parensim hepar disertai dilatasi sinusoid. Bentuk lobuli dan vena sentralis masih dapat diidentifikasi walaupun telah tampak celah interlobuli (Gambar 2). Penelitian ini agak berbeda dengan $\mathrm{Li}$ et $\mathrm{al}^{8}$ yang melaporkan terjadinya kongesti sinusoid hepar yang nyata setelah 25 menit postmortem. Pada penelitian tersebut $\mathrm{Li}$ et al. menggunakan hepar tikus yang diambil 25 menit postmortem. Terjadinya perbedaan waktu tersebut mungkin disebabkan karena perbedaan hewan coba yag digunakan dalam penelitian dan cara pengambilan sampel. Li et al. juga tidak mencantumkan suhu closed chamber yang digunakan untuk eutanasi hewan coba sehingga tidak dapat dibandingkan perbedaan suhu ruang antara kedua penelitian tersebut.

Bila dibandingkan dengan organ lain, saat terjadinya perubahan gambaran histologik hepar pada penelitian ini sesuai dengan yang dilaporkan Rahmadana et al. ${ }^{16}$ yang menggunakan ginjal hewan coba babi yaitu perubahan histologik yang paling dini (berupa degenerasi hidropik tubuli proksimal) dapat diidentifikasi 30 menit postmortem. Weight et al. dengan menggunakan ginjal tikus juga melaporkan bahwa perubahan morfologik ringan pada organ ginjal terjadi setelah $15-30$ menit. $^{17}$

Pada 45 menit dan 60 menit postmortem, perubahan-perubahan di atas makin nyata (Gambar 3). Hal ini disokong oleh hasil penelitian Tomita et al. ${ }^{5}$ yang mendapatkan pada autolisis perubahan ultrastruktur hepar dapat diamati 1 jam postmortem. Weight et al. yang menggunakan ginjal tikus juga menyatakan bahwa perubahan morfologik nyata terjadi setelah 45 menit. $^{17}$

Menurut $\mathrm{Li}$ et $\mathrm{al}^{8}{ }^{8}$ perubahan ultra struktur pada hepar tikus berupa vakuola hepatosit mulai tampak segera setelah kematian hewan coba, terutama pada hewan yang tidak dipuasakan. Karadzic et $\mathrm{al}^{3}$ yang meneliti hepar tikus melaporkan perubahan ultrastruktur hepatosit pada suhu $28^{0} \mathrm{C}$ terjadi pada 2 jam postmortem. Berdasarkan kedua penelitian di atas maka walaupun sampai dengan 60 menit postmortem pembuluh-pembuluh dalam area portal masih dapat diidentifikasi, mungkin telah terjadi disfungsi ultra struktur pembuluh-pembuluh tersebut. Perkiraan waktu ini sesuai dengan penelitian Weight et al. yang menyatakan setelah 60 menit telah terjadi perubahan morfologik berat. ${ }^{17}$

Pada 12 jam postmortem, perubahan histologik tersebut di atas makin meluas, bentuk lobuli heksagonal masih dapat diidentifikasi tetapi vena sentralis tidak jelas. Sebagian besar pembuluh-pembuluh dalam area portal tidak dapat diiden-tifikasi lagi (Gambar 4).

Pada 24 jam postmortem, lobuli hepar dan vena sentralis serta pembuluhpembuluh dalam area portal tidak dapat diidentifikasi lagi (Gambar 5). Hal ini disokong oleh penelitian Tomita et al. yang menyatakan perubahan ultra struktur hepar telah ditemukan sejak 1 jam postmortem, yang menjadi nyata 15 jam postmortem. ${ }^{5}$

Memperkirakan saat kematian yang mendekati ketepatan sangat penting dalam penyidikan. Faktor-faktor yang memengaruhi perubahan pada mayat yaitu terjadinya penurunan suhu; terbentuknya lebam 
mayat; terbentuknya kaku mayat; terjadinya pembusukan, adipocere dan mumifikasi serta terjadinya perubahanperubahan biokimiawi. Lebam mayat mulai tampak samar-samar 15-20 menit setelah mati somatis, makin lama makin nyata dan menetap 12 jam setelah mati. Kaku mayat mulai tampak 2-4 jam. Suhu mayat pada 30-60 menit pertama tidak mengalami penurunan. Setelah selang waktu tersebut suhu tubuh mayat akan turun sampai sama dengan suhu keliling. ${ }^{2}$

Gambaran histologik postmortem hewan coba pada penelitian ini sudah menunjukkan perubahan histologik hepar hewan coba 30 menit postmortem (Gambar 2), yang makin nyata pada 45 dan 60 menit postmortem. Setelah 12 jam postmortem, terdapat perubahan histologik yang drastis dimana sebagian besar vena sentralis dan pembuluh-pembuluh dalam area portal tidak dapat diiden-tifikasi lagi.

Perubahan-perubahan histologik tersebut dapat diidentifikasi secara sederhana dan diharapkan dapat diaplikasikan dalam penentuan saat kematian dini $(<24$ jam), terlebih lagi pada kondisi mayat yang mengalami trauma fisik yang luas (antara lain: gigitan binatang buas, tindakan kekerasan) atau kasus mutilasi dimana tanda-tanda kematian seperti kaku mayat dan lebam mayat sulit dinilai. ${ }^{6}$ Penelitian lanjut yang lebih detail perlu dilakukan mengingat terdapatnya perbedaan struktur histologik dan fisiologi antara organ-organ manusia dan hewan coba yang dapat memengaruhi proses dekomposisi.

\section{SIMPULAN}

Berdasarkan hasil penelitian dapat disimpulkan bahwa perubahan gambaran histologik hepar babi mulai tampak pada menit ke 30 postmortem ditandai kongesti jaringan parensim hepar disertai dilatasi sinusoid. Pada 12 jam postmortem, perubahan histologik tersebut di atas makin nyata, bentuk lobuli heksagonal masih dapat diidentifikasi tetapi vena sentralis dan sebagian besar pembuluh-pembuluh dalam area portal tidak dapat diidentifikasi. Pada
24 jam postmortem struktur hepar tidak dapat diidentifikasi lagi.

\section{SARAN}

Parameter waktu pada manusia masih sulit ditentukan mengingat sulitnya subjek penelitian. Selain itu, terdapat perbedaan histofisiologik organ-organ manusia dan hewan coba. Oleh karena itu perlu dilakukan penelitian lebih lanjut dengan sampel yang lebih banyak, menggunakan waktu yang lebih rinci terlebih lagi setelah 60 menit postmortem, dan pada organorgan lain dengan interval waktu yang lebih rinci

\section{UCAPAN TERIMA KASIH}

Ucapan terima kasih ditujukan kepada dr. G. N. Tanudjaja, MSi, PA(K), dr. Martha M. Kaseke, M.Kes, Dr. dr. Erwin G. Kristanto, SH, SpF, dan dr. Poppy M. Lintong, SpPA(K), dan semua pihak baik secara langsung maupun tidak langsung yang telah menumbuhkan ide dan gagasan pada penulis.

\section{DAFTAR PUSTAKA}

1. Perkiraan saat kematian [homepage on the Internet]. 2005 [cited: 2013 Oct 17]. Available from: http://forensicpathology.webs.com/.

2. Idries AM. Pedoman Ilmu Kedokteran Forensik. Jakarta: Binarupa Aksara, 1997; p. 56-57, 106.

3. Karadzic R, Ilic G, Antovic A, Banovic LK. Autolytic ultrastructural changes in rat and human hepatocytes. Rom J Leg Med. 2010;18:247-52.

4. Zdaravkovic M, Kostov M, Stojanovic M. Identification of postmortem autolytic changes on the kidney tissue using PAS stained method. Medicine and Biology. 2006;13(3):181-4.

5. Tomita $Y$, Nihira $M$, Ohno $Y$, Sato S. Ultrastructural changes during in situ early postmortem autolysis in kidney, pancreas, liver, heart and skeletal msucle of rats. Legal Medicine. 2004;6:25-31. 
6. Kushwaha V, Yadav M, Srivastava AK, Agarwal A. Time since death from degenerative changes in the kidney. $\mathrm{J}$ Indian Acad Forensic Med. 2010;32(1):37-41.

7. Tomita Y, Nihira M, Ohno Y, Sato S. Histological study of early postmortem changes in various organs: comparison of the paraffin embedding method and the epoxy resin embedding method. Nihon Hoigaku Zasshi. 1999;53(2):207-17.

8. Li X, Elwell MR, Ryan AM, Ochoa R. Morphogenesis of postmortem hepatocyte vacuolation and liver weight increases in Sprague-Dawley rats. Toxicol Pathol. 2003;31:682-8.

9. Pratama AA. Hubungan antara lama waktu kematian dengan kerusakan histopatologik otot jantung tikus Wistar [Skripsi]. Semarang: Universitas Diponegoro; 2010.

10. Campobasso CP, Di Vella G, Introna F. Factors affecting decomposition and diptera colonization. Forensic Science Internasional. 2001;120:18-27.

11. Dadour LR, Cook DF, Fissioli JN, Bailey WJ. Forensic entomology: application, education and research in Western Australia. 2001. Forensic Science International. 2001;120:48-52.
12. Lecese A. Insects as forensic indicators: Methodological aspects. Aggrawal's Internet Journal of Forensic medicine and Toxicology. 2004;5(1):26-32

13. Wangko S. 2012. Kajian gelombang suksesi serangga forensik pada bangkai hewan coba di kota Manado, Indonesia [Disertasi]. Manado: Universitas Sam Ratulangi, 2012.

14. Swine as models in biomedical research and toxicology testing. 2012 [cited: 22/01/2014] Available from: http:// vet.sagepub.com/content/49/2/344.full. pdf+html.

15. Kimura M, Abe M. Histology of postmortem changes in rat livers to ascertain hour of death. Int $\mathrm{J}$ Tissue React. 1994;16(3):139-50.

16. Baldatun R, Wangko S, Kalangi SJR. Gambaran histologik ginjal hewan coba postmortem. e-Biomedik. 2014;2(2).

17. Piazza O, Romano R, Cotena S, Santaniello W, Robertis ED. Maximum tolerable warm ischaemia time in transplantation from non-heartbeating-donors. 2013 [cited 2013 Sep 20]. Available from: https://www. academia.edu/2517011/Maximum_toler able_warm_ischaemia_time_in_transpl antation_from_non-heart-beatingdonors. 